\title{
Framing Pemberitaan Citra Politik Capres 2014 Di Harian Solopos
}

\author{
Puji Widi Astutik \\ (pujiwidi@yahoo.com) \\ (Alumni Ilmu Komunikasi FTIK USM)
}

\begin{abstract}
The article tries to find out the construction of the image formation in the daily Solopos 2014 candidates. Basic theoretically in this paper uses descriptive analysis method with a form of text analysis models Zhongdang Pan and Gerald M. Kosicki through four units of analysis, syntax, script, thematic, and Rhetorical . Framing analysis is used to see how the image formation through the political news in the Daily Solopos 2014 candidates. Through this analysis can be found that the construction of a shadow image ( mirror image) performed on the outlook for both candidates figure formed by the track record of each kandindat. Joko Widodo figure in the frame with the figure of the fight for the people and work for the people, while the figure Prabowo has a bad track record as it is considered to participate in the abduction tragedy in which 98 activists at that time as a military prabowo
\end{abstract}

Kata Kunci: Kontruksi Citra, Framing

\section{Pendahuluan}

Menjelang Pemilihan umum Presiden dan wakil Presiden, seperti pemilihan tahun lalu pemilu kembali digelar di tahun 2014, berbagai cara untuk memperoleh suara rakyat yang digunakan oleh kandidat Capres dan Cawapres. Melalaui kegiatan pemaparan visi,misi, program rencana kerja yang dikemukakan kepada rakyat, melalui media massa. Upaya memenangkan ajang pemilihan secara langsung tentunya dibutuhkan strategi yang tepat untuk dapat meraih suara pemilih berbagai cara dilakukan untuk dapat meraih suara pemilih, antara lain melakukan politik pencitraan didalamnya dengan menggunakan strategi pemasaran politik dalam berbagi hal. Peran media massa dalam proses pemilu sangat signifikan dan bertumbuh pesat, mengupas tuntas dari berbagai sudut pemberitaan mengenai politik, isu kampanye dan sebagainya. Menurut Dennis McQuail salah satu fungsi sentral media massa sebagai fungsi kolerasi sosial (social correlation).

Melalui berita dan opini yang dimuat secara reguler, media memandu publik menghubungkan berbagai realitas yang sebelumnya terpisah oleh faktor geografi dan psikografi, menjadi satu rangkaian yang mudah dipahami dan diikuti. Kekuatan media dalam melakukan Framing atas sebuah teks dan fakta memandu publik mengkolerasinya ke dalam konteks ekonomi, sosial politik dan budaya pada kurun waktu tertentu (McQuail,1994 dalam 
masduki jurnalisme positif keberpihakan media dalam pemilu). Berdasarkan pernyataan diatas dapat disimpulkan bahwa peran media massa sebagai salah satu penghubung menyampaikan suatu informasi. Media massa melakukan Produksi berita yang dipengaruhi oleh berbagai faktor internal dan faktor eksternal. Faktor internal antara lain berupa kebijakan redaksional tertentu mengenai kekuatan politik, kepentingan politik para pengelola media, relasi media dengan sebuah kekuatan politik tertentu. Sementara faktor eksternal berupa tekanan pasar pembaca atau pemirsa, sistem politik yang berlaku dan kekuatan-kekuatan luar lainnya.

Media massa memiliki dua peran penting dalam politik. Pertama, media adalah sumber informasi penting bagi kepentingan politik; kedua, media dapat mempengaruhi keputusan pemilih secara langsung melalui dukungan dan editorial, dan secara tidak langsung, media adalah kendaraan bagi partai politik maupun kandidat yang merupakan panggung dalam menyampaikan visi dan misi. Media menjadi lahan strategis dalam menyampaikan pesan-pesan politik kepada masyarakat yakni dalam pembentukan opini publik dan dalam membangun citra politik. Media turut berkontribusi dalam meningkatkan kualitas penyelenggaraan dan kualitas kandidat Pemilu 2014, sebuah teks yang dihasilkan oleh media massa, khususnya berkaitan dengan sebuah parpol, mempunyai dua fungsi sekaligus, yakni sebagai teks media yang dapat dinikmati oleh khalayak dan sebagai teks public relations yang merupakan tujuan dari parpol sebagai upaya untuk membentuk citra kepada khalayak, sehingga pembentukan citra yang dilakukan oleh parpol dapat tercapai dengan maksimal.

\section{Tinjauan Pustaka}

Framing adalah salah satu metode penelitian yang termasuk baru dalam dunia ilmu komunikasi. Framing sering digunakan untuk menggambarkan proses seleksi dan penonjolan aspek tertentu dari realitas oleh media. Framing dipandang sebagai penempatan informasi-informasi dalam konteks yang khas sehingga isu tertentu mendapatkan alokasi lebih besar daripada isu yang lain. Analisis framing salah satu metode analisis teks yang berada dalam kategori penelitian konstruksionis (Eriyanto, 2002:43). Framing didefinisikan sebagai proses membuat suatu pesan lebih menonjol, menempatkan informasi lebih daripada yang lain sehingga khalayak lebih tertuju pada pesan tersebut.

Menurut Pan dan Kosicki, ada dua konsepsi psikologi. Framing dalam konsep ini lebih menekankan pada bagaimana seseorang mengolah sejumlah informasi dan ditujukan dalam skema tertentu. Framing dilihat sebagai penempatan informasi dalam suatu konteks yang unik/ khusus dan menempatkan elemen tertentu dari suatu isu dengan penempatan lebih menonjol dalam kognisi seseorang. Elemen elemen yang diseleksi dari suatu isu/ peristiwa tersebut menjadi lebih penting dalam mempengaruhi pertimbangan dalam membuat keputusan tentang realitas. Kedua, konsepsi sosiologis dipahami sebagai proses bagaimana seseorang 
mengklarifikasi, mengorganisasi dan menafsirkan pengalaman sosial untuk mengerti dirinya dan realitas diluar dirinya.

Pandangan psikologis lebih melihat pada proses internal sesorang, bagaimana individu secara kognitif menafsirkan suatu peristiwa dalam cara pandang tertentu, maka pandangan sosiologis lebih melihat pada bagaimana konstruksi sosial atas realitas. (Eriyanto,2002:252). Frame dipahami sebagai proses bagaimana seseorang mengklasifikasi, mengorganisasikan dan menafsirkan pengalaman sosialnya untuk mengerti dirirnya dan realitas di luar dirinya. Frame di sini berfungsi membuat suatu realitas menjadi teridetifikasi, dipahami, dan dapat dimengerti. analisis

framing sebagai pengembangan lebih lanjut dari analisis wacana, Pan dan Kosicki mengklasifikasikan perangkat framing ke dalam empat kategori yaitu struktur, sintaksis, struktur skrip, struktur tematik dan struktur retoritis. (Eriyanto,2002: 253).

\section{Kontruksi Sosial}

Teori konstruksi sosial, sejatinya dirumuskan kedua akademisi ini sebagai suatu kajian teoretis dan sistematis mengenai sosiologi pengetahuan. Istilah konstruksi atas realitas sosial (social construction of reality) menjadi terkenal sejak diperkenalkan oleh Peter L. Berger dan Thomas Luckman melalui bukunya yang berjudul The Social Construction of Reality: A Treatise in the Sociological of Knowledge (1966). Ia menggambarkan proses sosial melalui tindakan dan interaksinya, dimana individu menciptakan secara terus menerus suatu realitas yang dimiliki dan dialami bersama secara subyektif. Susbtansi teori dan pendekatan konstruksi sosial ini merupakan sebuah realitas pada proses simultan yang terjadi secara alamiah melalui bahasa dalam kehidupan sehari-hari pada sebuah komunitas primer dan semi sekunder.

Berger dan Luckman (Bungin, 2008:14) menjelaskan realitas sosial dengan memisahkan pemahaman 'kenyataan dan pengetahuan'. Realitas diartikan sebagai kualitas yang terdapat di dalam realitas-realitas yang diakui sebagai memiliki keberadaan (being) yang tidak tergantung kepada kehendak kita sendiri. Pengetahuan didefinisikan sebagai kepastian bahwa realitas-realitas itu nyata (real) dan memiliki karakteristik yang spesifik. Berger dan Luckman (Bungin, 2008:15) mengatakan terjadi dialektika antara indivdu menciptakan masyarakat dan masyarakat menciptakan individu. Proses dialektika ini terjadi melalui eksternalisasi, objektivasi, dan internalisasi.

Proses dialektis tersebut mempunyai tiga tahapan; Berger menyebutnya sebagai momen. Ada tiga tahap peristiwa. Pertama, eksternalisasi, yaitu usaha pencurahan atau ekspresi diri manusia ke dalam dunia, baik dalam kegiatan mental maupunfisik. Kedua, objektivasi, yaitu hasil yang telah dicapai baik mental maupun fisik dari kegiatan eksternalisasi manusia tersebut. Hasil itu menghasilkan realitas objektif yang bisa jadi akan menghadapi si penghasil itu sendiri sebagai suatu faktisitas yang berada 
di luar dan berlainan dari manusia yang menghasilkannya. Lewat proses objektivasi ini, masyarakat menjadi suatu realitas suigeneris.

Hasil dari eksternalisasi kebudayaan itu misalnya, manusia menciptakan alat demi kemudahan hidupnya atau kebudayaan nonmateriil dalam bentuk bahasa. Baik alat tadi maupun bahasa adalah kegiatan ekternalisasi manusia ketika berhadapan dengan dunia, ia adalah hasil dari kegiatan manusia. Ketiga, internalisasi. Proses internalisasi lebih merupakan penyerapan kembali dunia objektif ke dalam kesadaran sedemikian rupa sehingga subjektif individu dipengaruhi oleh struktur dunia sosial.Melalui internalisasi, manusia menjadi hasil dari masyarakat. Bagi Berger, realitas itu tidak terbentuk secara ilmiah, tidak juga sesuatu yang diturunkan oleh Tuhan. Tetapi sebaliknya, ia dibentuk dan dikonstruksi.

\section{Kontruksi Sosial Media Massa}

Substansi teori kontruksi sosial media massa adalah sirkulasi informasi yang cepat dan luas sehingga kontruksi sosial berlangsung dengan sangat cepat dan seberannya merata. Realitas yang terkontruksi itu juga membentuk opini massa, massa cenderung apriori dan opini massa cenderung sinis (Bungin, 2008:203). Tahapan dalam proses konstruksi sosial media massa melalui tahapan sebagai Proses konstruksi sosial media massa melalui tahapan yang menyiapkan materi konstruksi : tahap sebaran kontruksi, tahap pembentukan konstruksi; tahap konfirmasi (Bungin 2008:188-189). Tahapan menyiapkan materi kontruksi: ada tiga hal dalam tahapan ini yaitu keberpihakan media massa kepada kapitalisme, keberpihakan semu kepada masyarakat, keberpihakan kepada kepentingan umum.

Tahap sebaran kontruksi: prinsip dari dasar tahapan sebaran kontruksi sosial media massa adalah semua informasi harus sampai pada khalayak secara tepat berdasarkan agenda media. Sebagaimana apa yang di pandang penting oleh media, menajdi penting pula bagi pembaca,Tahapan pembentukan kontruksi realitas.Dimana pembentukan kontruksi berlangsung melalui kontruksi realitas pembenaran, kesediaan dikontruksi oleh media massa, sebagai pilihan konsumstif.Tahapan konfirmasi dimana sebuah media massa memberi argumentasi dan akuntabilitas terhadap pilihannya untuk terlibat dalam pembentukan kontruksi.

\section{Citra Politik}

Citra adalah bagian front image atau sampul (cover), citra kandidat bagian yang mengulas mengenai image calon. Citra politik dapat dipahami sebagai gambaran seseorang yang terkait dengan politik (kekuasaan, kewenangan, otoritas, konflik, dan konsesus). Citra politik tersusun melalui persepsi yang bermakna tentang gejala politik dan kemudian menyatakan makna itu melalui kepercayaa, nilai, dan pengharapan dalam bentuk pendapat pribadi yang selanjutnya dapat berkembang menjadi opini publik. citra politik dapat dirumuskan sebagai gambaran tentang politik yang tersusun melalui kepercayaan, nilai, dan pengharapan dalam bentuk pendapat pribadi yang selanjutnya dapat berkembang menjadi pendapat umum.

Citra politik itu terbentuk berdasarkan informasi yang kita terima, baik langsung maupun melalui media politik, termasuk media massa yang bekerja untuk menyampaikan pesan politik yang umum dan aktual. Citra seseorang tentang politik terjalin melalui pikiran 
dan pemahaman tentang peristiwa politik dan menghubungkan pandangan umum tentang diri dengan orang lain.Persaingan untuk memperebutkan hati dan perhatian masyarakat tidak dapat dilakukan sendiri oleh partai politik dan konstentan partai dan disinilah penggunaan media sebagai penyebar informasi, program kerja dan produk politik akan lebih efektif.

Citra memiliki empat fase. Yang pertama, representasi dimana citra merupakan cermin suatu realitas, kedua, ideologi dimana citra menyembunyikan dan memberi gambaran yang salah akan realitas. Ketiga, citra menyembunyikan bahwa tidak ada realitas. Keempat, citra tidak memiliki sama sekali hubungan dengan realitas apapun. (Baudrillaard dalam arifin 2011:193). Citra terbentuk berdasarkan pengetahuan dan informasi informasi yang diterima seseorang. Menurut (Jefkins,2004 :20) citra dibagi beberapa jenis, yakni :

1. Citra bayangan (miror image), merupakan citra yang dianut oleh orang atau anggota / organisasi mengenai pandangan pihak luar terhadap organisasinya.

2. Citra yang berlaku (current image) yaitu citra atau pandangan yang dianut oleh pihak pihak luar mengenai suatu organisasi.

3. Citra yang diharapkan (Wish image) citra yang diinginkan oleh pihak manajemen.

Biasanya lebih baik atau lebih menyenangkan daripada citra yang ada.

4. Citra perusahaan (corporate image), yaitu citra dari suatu organisasi secara

keseluruhan, bukan sekedar citra akan produk dan pelayanan yang diberikan.

5. Citra majemuk (multiple image) citra yang beraneka ragam yang hampir sama banyaknya dengan jumlah pegawai yang dimiliki oleh organisasi/perusahaan.

\section{Kerangka Berfikir}

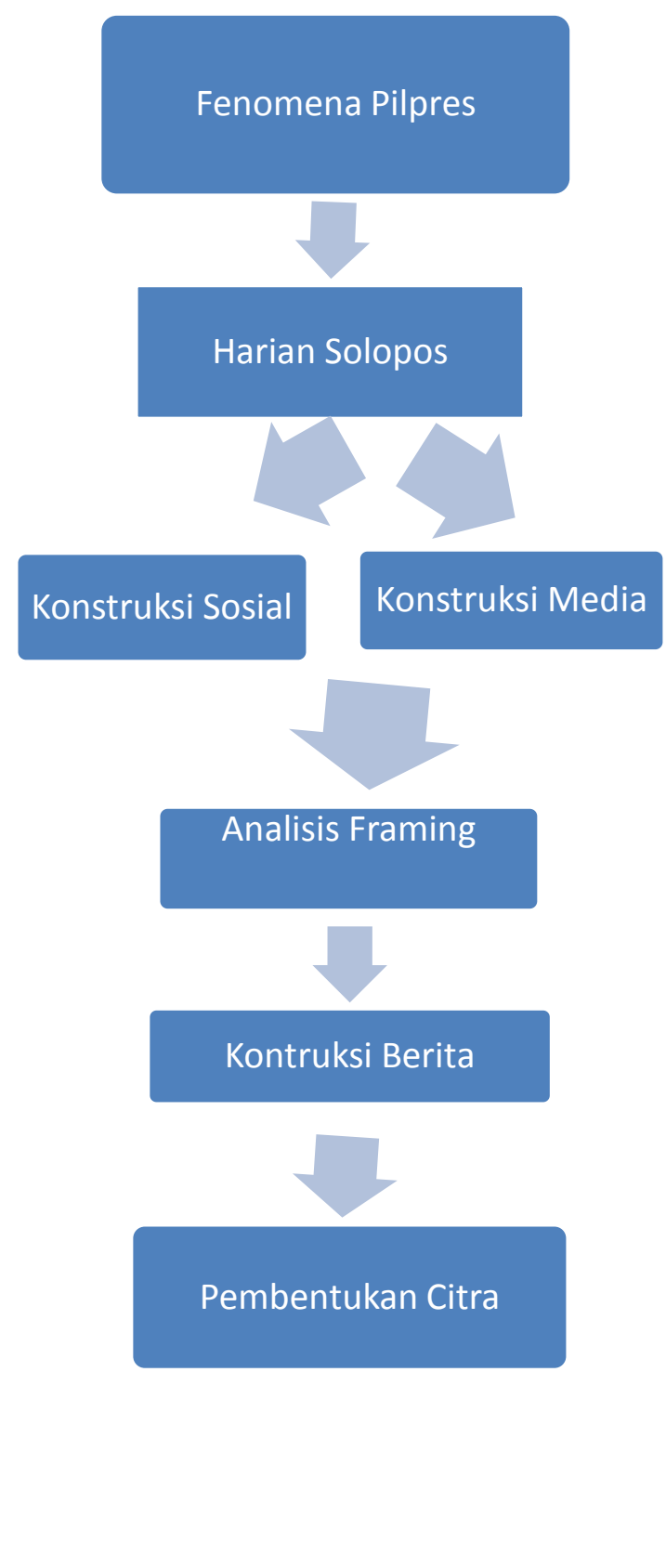




\section{Pembahasan}

Citra yang dibentuk melalui pemberitaan media tentang kedua kandidat yang dimuat di Harian Solopos melalui proses pembelajaran politik baik secara langsung maupun melalui pengalaman empirik. Pembentukan citra Joko Widodo melalui teks di asumsikan sebagai sosok yang jujur merakyat hal ini terlihat dalam teks Gubenur nonaktif DKI Jakarta menjelaskan kemenangan ini adalah kemenangan untuk seluruh rakyat Indonesia. Diharapkan kemenangan rakyat ini akan melapangkan jalan untuk mencapai dan mewujudkan Indonesia yang berdaulat secara politik, berdikari, secara ekonomi, dan berkepribadiam secara kebudayaan.

Proses pembentukan citra melalui bayangan, kesan atau gambaran tentang suatu obyek terutama kandindat politik, elite politik dan pemerintah. Kontruksi citra yang dilakukan mengenai pandangan kepada sosok kedua kandidat yang dibentuk melalui rekam jejak masing masing kandindat. Menurut (Jefkins,2004 :20) Citra bayangan (miror image), merupakan citra yang dianut oleh orang atau anggota/ organisasi mengenai pandangan pihak luar terhadap organisasinya. Citra bayangan (miror image) yang dilakukan mengenai pandangan kepada sosok kedua kandindat yang dibentuk melalui rekam jejak serta aktivitas masing masing kandindat.

Dalam hal ini miror image terlihat dalam teks berita kemenangan Joko
Widodo yang di asumsikan sosok yang berjuang untuk rakyat serta kemenangan Joko Widodo untuk rakyat. Sedangkan pembentukan Citra Prabowo Subianto di asumsikan mempunyai rekam jejak yang buruk hal ini terlihat dari teks Advokat merah putih, yang kedua Empat lembaga pembela HAM yaitu Kontras, Setara Institute, Imparsial dan perhimpunan Bantuan hukum Indonesia (PBHI) mengajukan gugatan hukum terhadap KPU melalui PTUN mereka menggugat KPU terkait penetapan Prabowo sebagai capres. Ketua Badan Pengurus Setara Institute Hendardi menjelaskan gugatan diajukan karena Prabowo memiliki rekam jejak buruk di bidang HAM.

Dari pengamatan melalui analisis framing, peneliti menemukan bahwa Solopos berusaha mengajak pembaca untuk lebih dekat melihat realitas yang sebenarnya,informasi yang disajikan menggunakan bahasa sebagai simbol yang utama, wartawan mampu menciptakan, mengembangkan suatu realitas, maka dalam hal ini wartawan Solopos mengajak pembaca lebih mengenal calon Presiden lebih dekat lagi menjelang pemilu 2014 melalui artikel artikel yang disajikan.Menurut teori konstruksi sosial, yang dikemukakan Berger dan Luckman (Bungin,2008: 15) mengatakan dialektika antara individu menciptakan masyarakat dan masyarakat menciptakan individu.

Dari struktur tematik, berita itu membawa dua tema besar yang ingin ditampilkan khalayak yaitu, pelanggaran pencapresan Joko widodo yang melanggar aturan 
hukum formal oleh pernyataan pihak Aliansi Advokat merah putih, yang kedua Empat lembaga pembela HAM yaitu Kontras, Setara Institute, Imparsial dan perhimpunan Bantuan hukum Indonesia (PBHI) mengajukan gugatan hukum terhadap KPU melalui PTUN mereka menggugat KPU terkait penetapan Prabowo sebagai capres. Ketua Badan Pengurus Setara Institute Hendardi menjelaskan gugatan diajukan karena Prabowo memiliki rekam jejak buruk di bidang HAM.

Nilai berita proximity (kedekatan) suatu peristiwa baik kedekatan secara geografis maupun emosional di tampilkan pihak Solopos dalam frame berita dengan Headline "Wong Solo Presiden" merupakan salah satu kontsruksi berita yang dibentuk melalui Proses Gatekeepingyang dilakukan oleh pihak Redaksi Solopos dengan menunjukan suatu kedekatan secara geografis dengan salah satu Capres yang menjadi pemenang Pemilu 2014.

\section{Kesimpulan}

Bab ini berisi tentang kesimpulan dari penelitian yang telah dilakukan oleh peneliti berdasarkan analisis Framing Pan dan Kosicki tentang pembingkaian berita yang terjadi di Harian Solopos. Sosok Joko Widodo dinilai Sosok yang memperjuangkan rakyat dan bekerja untuk rakyat hal ini terlihat pada teks Wong Solo Presiden "Gubenur nonaktif DKI Jakarta menjelaskan kemenangan ini adalah kemenangan untuk seluruh rakyat Indonesia. Diharapkan kemenangan rakyat ini akan melapangkan jalan untuk mencapai dan mewujudkan Indonesia yang berdaulat secara politik, berdikari, secara ekonomi, dan berkepribadiam secara kebudayaan". Dalam teks tersebut sosok Joko Widodo sosok yang merakyat dan kemenangannya dalam Pilpres 2014 itu karena dukungan Rakyat.Sementara itu sosok Prabowo Subianto dinilai mempunyai rekam jejak yang buruk terhadap HAM hal ini terlihat tentang gugatan yang dilakukan Aliansi Institute serta pemasangan atribut spanduk yang kedua bergambar aktivis 98 korban penculikan disandingan dengan gambar Prabwo subianto dengan tulisan "Sang Capres penculik, kembalikan Kawan Kami”.

Sosok Prabowo dinilai ikut dalam tragedi penculikan aktivis 98 dimana pada saat itu prabowo sebagai militer. Hasil Framing yang dilakukan oleh peniliti pihak Solopos berusaha menghadirkan informasi yang berimbang baik sisi positif maupun negatif dari kedua sosok tersebut. Kontruksi pembentukan citra Capres yang dihadirkan Solopos melalui frame berita yang memperhatikan nilai Kedekatan (proximity) suatu peristiwa yang dekat dengan pembaca baik secara geografis maupun emosional. Hal ini bisa di lihat dalam frame salah satu headline Solopos dimana menggunakan judul "Wong Solo Presiden" sebagaimana Solopos membingkai Pemilu 2014 berhasil di menangkan oleh Joko Widodo dengan memperhatikan faktor kedekatan geografis.

Kontruksi citra bayangan (miror image) yang dilakukan mengenai pandangan kepada sosok kedua kandidat yang dibentuk melalui rekam jejak masing masing kandindat. Pembentukan citra politik terkait dengan sosialisasi politik hal 
ini disebabkan karena citra politik terbentuk melalui proses pembelajaran politik baik secara langsung maupun pengalaman empirik. Seluruh pengetahuan politik seseorang(kognisi), baik benar maupun keliru. Citra yang dibentuk oleh masing masing kandidat melalui aktivitas masing masing kandidat. Pembentukan citra politik terkait dengan sosialisasi politik hal ini disebabkan karena citra politik terbentuk melalui proses pembelajaran politik baik secara langsung maupun pengalaman empirik. Seluruh pengetahuan politik seseorang(kognisi), baik benar maupun keliru. Citra yang dibentuk oleh masing masing kandidat melalui aktivitas masing masing kandidat.Citra politik terbentuk melalui media sebagai fungsinya memberikan sebuah informasi baik langsung maupun melalui media itu sendiri untuk menyampaikan pesan politik yang umum dan aktual.

Persaingan untuk memperebutkan hati dan perhatian masyarakat tidak dapat dilakukan sendiri oleh partai politik dan konstentan partai dan disinilah penggunaan media sebagai penyebar informasi, program kerja dan produk politik akan lebih efektif. Selanjutnya Peneliti melakukan wawancara kepada Redaktur Rubrik Pilpres Syifaul Arifin, Harian Solopos melakukan kontruksi berita secara berimbang memberikan informasi informasi kepada masyarakat sebagai sarana edukasi sebelum melakukan pemilihan. Untuk keberimbangan harian Solopos tidak menutup mata oriantasi Ekspolarasi yang dihadirkan Solopos di sesuaikan dengan keinginan pangsa pasar.
Faktor kedekatan salah satu Capres menjadi pertimbangan sendiri oleh Harian Solopos. Hasil Kontruksi dari kedua Capres dan Cawapres dihadirkan secara proposional bukan partisan.

Selain melakukan wawancara kepada pihak redaktur penulis juga melakukan wawancara dengan salah satu Dosen Fisip Universitas Sebelas Maret. Hasil wawancara yang di lakukan oleh peneliti kepada Drs. Eko Setianto sebagai penguat hasil kesimpulan. Untuk pilpres tahun 2014 berbeda dengan pilpres lima tahun sebelumnya bisa di lihat dari peserta Pilpres 2014 serta rivalitas Capres tahun ini begitu terlihat dari pendukung masing masing Capres mengahsilkan sikap fanatisme dan mengakibatkan kehilangan rasionalitas hal ini menimbulkan Black Campaign. Untuk harian Solopos telah menghasilkan informasi sesuai koridor dengan kaidah jurnalistik. keberpihakannya mungkin ada dilihat secara letak geografis dan emosional dekat dengan salah satu Capres. Solopos bukan termasuk media partisan karena berusaha menjaga netralitas dalam batas tertentu dengan koridor yang wajar.

\section{Daftar Pustaka}

Berger, Peter L and Thomas Luckman. "The Social Construction of Reality A Treatise in The Sosiologi of Knowledge, Penerj. Hasan Basari dalam Skripsi Donny Kadewandana Jakarta:LP3ES, 1990

Burhan Bungin, 2007, Sosiologi Komunikasi: Teori, Paradigma dan Diskursus Teknologi 
Komunikasi di Masyarakat, Jakarta; Kencana

Eriyanto. 2007 Analisi Framing: "Kontruksi, Ideologi Dan Politik Media." Lkis, Yogyakarta.

Hamad, Ibnu 2004 "Konstruksi Realitas Politik dalam media massa. Jakarta.

Jefkins, Franks. 2002 "Public relations".Erlangga, Jakarta.

Marzuki. 2002 ."metodologi riset. BPFE UII Yogyakarta: yogyakarta.

Mc Quail Denis, 2011 Teori Komunikasi Massa. Jakarta: Salemba Humanika.

Nursal, Adman 2004, Political Marketing, Jakarta Gramedia pustaka utama.

Putra Dedi Kurnia Syah, 2012 "Media Dan Politik"; Graha Ilmu, Yogyakarta.

William A.Gamson, David Croteau, William Hoynes and Theordore Sasson, "Media Images And The Social Construction of Reality", Annual Riview of Sosiology, Vol 18,1992, hal 374-375 dalam buku Eriyanto "Kontruksi, Ideologi Dan Politik Media,2007,LKIS; Yogyakarta 